\title{
Applications of Surveying and Geoinformatics for Planning New Routes to Solve Traffic Congestion in part of Minna Metropolis (Kpakungu, a case study)
}

\author{
Onuigbo I. C. ${ }^{1, *}$, Adewuyi T. ${ }^{1}$, Odumosu J. O. ${ }^{1}$ and Oluibukun G. A. ${ }^{1}$ \\ ${ }^{1}$ Department of Survey and Geoinformatics, Federal University of Technology, Minna, Nigeria \\ Corresponding Author: *anyi.onuigbo@futminna.edu.ng
}

\begin{abstract}
The volume of traffic generated by land-use pattern varies during different periods of the day but there is usually a predictable pattern of such traffic volumes. Most often, the structure of urban land-use fails to provide easy and convenient traffic movement, which in the case of the study area is usually that of vehicles and pedestrian traffic. The fact is that Minna is presently experiencing rapid urban growth. Both the authorities and citizens seem to simply ignore this and its impact on human existence. The research is based on Road Traffic Network Analysis in Minna, to develop a road network map and determine the causes of Traffic Congestion in Kpakungu specifically. Quickbird satellite imagery was used in analyzing and mapping out the existing road network within the study area. Field survey aspects involving measuring of roads, traffic count, coordinates captured were also undertaken. It was discovered that the causes of the traffic pressure in the study area was as a result of the relocation of Federal University of Technology, Minna to its permanent site in Gidan Kwanu and the relocation of National Examination Council(NECO) Headquarter. Majority of the traffic pressure in the area were as a result of vehicles coming from Maikunkele, Bosso, Maitumbi, Minna central, Dutsen Kura, Chanchaga, Tunga, Sahuka-kahuta and BarikinSale going to Bida, Gidan-Kwanu or NECO office. It was concluded that alternative roads should be provided for vehicle diversion to limit the congestion of traffic on the road.
\end{abstract}

Keywords: Traffic, Development, Mapping, Traffic congestion, Satellite imagery

\subsection{Introduction}

Traffic in an urban area is necessitated by the need for various parts to relate with one another. The volume of traffic generated varies during different periods of the day but there is usually a predictable pattern of such traffic volumes. Inconvenient traffic movement generates many problems such as unnecessary longer travel times, environmental pollution, crime, emotional and psychological stress (Leke, 2007).

Minna is the capital city of Niger State, largely populated because of the commercial activities going on within the town. Considering the fact that Minna is the capital, one should expect the influx of civil servants into the city. Both State and Federal Government workers within the state will most likely reside in the city for easy access to their different places of work.

In 2007 the population of Minna was estimated to be 304,113 and it is growing steadily. Minna is in west central Nigeria and is the headquarters of Chanchaga Local Government Area. Traffic and transportation problem in Minna capital city of Niger State have become grave matters of concern to the government. A strategic planning of transport systems will alleviate these problems to a greater extent. Transportation planning process consists of analysis of interaction between supply in the form of existing facilities and the demand in the form of traffic load. It also involves forecasting for the future and evaluation of the alternatives arrived at the planning stage (Garba, 2002). 
The fact is that Minna is presently experiencing rapid urban growth. Both the authorities and citizens seem to simply ignore this and its impact on transportation. High population density, the bumps put by people of that area, narrow route, high vehicular movement at the peak hours because of the schools located in that route, hawkers along the route, motor parks along the route, road works, as well as trucks and vehicle stopping by the road side to offload goods are all causes of traffic congestion in that route.

The effects of these are parking problems, long delays to and from work, less productivity from employees, accident due to frustration or anger due to traffic jams, pollution as a result of car emission, and less attractive place to live. This research seeks to find out possible solutions for solving the traffic congestion of this area.

The aim of the research is to solve the problem of traffic congestion at Kpakungu. The objectives include: (1) mapping out the existing road network within and around Kpakungu area in Minna (2) obtaining the geospatial related attribute information, such as road name, road network, traffic volume, etc. for each of the roads (3) using satellite image to map out the congestion area (4) finding alternative route to take in order to bypass traffic congestion on the major road.

\subsection{Overview of Geographic Information System in routing}

Longley et al. (2001) view GIS from viewpoints of professionals and what they can do with the tool. In succinct form, a GIS is an integrated system for handling and analyzing geographic data. The power of a GIS lies in its ability to bring both spatial and attribute data within a common framework to form a unified database system; and its ability to compare different entities based on their common geographic occurrence through the overlay process.

Ogunbodede (2011) explained that GIS is a tool that can be used to sustain an endurable flow of traffic in urban environment, provided it is built on a properly designed database, which must also be amenable to constant updating.

Ammar et al. (2011) examined the value of real-time traffic information gathered through GIS for achieving an optimal vehicle routing within a dynamically stochastic transportation network. These features will help users and vehicle drivers in improving their service levels and productivity as the web application enables them to interactively find the optimal path to reach their destinations.

Mukti et al. (2011) developed a GIS based model with an objective of minimizing travel distance and travel time of users. GIS provides a powerful, logical, and intuitive means to store, manipulate, and retrieve data. In addition to promoting linkage between various types of data and maps GIS is able to manipulate and visually display numerous types of data for easy comprehension. GIS is a tool for managing and processing location and related information. It visually displays the results of analyses thus enabling sophisticated analysis and quick travel distance and travel time of users (Rodrigue et al., 2006).

Dynamic data relevant to route performance including details such as current traffic flow or speed, weather, road surface conditions and variations in road usage patterns due to events such as accidents, road maintenance or sports fixtures should be provided to emergency service providers (Harrington and Cahill, 2004). This database and GIS together can be helpful in finding the accidents on the road network and the shortest and fastest route to the accident site.

GIS based transportation data is collected from different sources such as GPS, topography, photos, remote sensors, etc. When GIS is applied to transportation, this is more than just a sphere of application of their generic functionality (Thill, 2000). GIS is used for modeling of road networks offering algorithms to analyze and find the shortest or minimum route through a network. GIS can be used to calculate distance, set locations and assign demand to sites. Street addresses can be converted to map coordinates (address Geocoding) (Golderg, 2011). 
GIS is mostly employed today in operational research as a one way data feeder for mathematical models (Erkut et al., 2001) and successfully provides distance and time for their emergency services districting and location problems.

A graphical user interface allows displaying and manipulating graphical objects; data storage and processing allows an eased interaction with the mathematical optimizer. However, the efficiency of a combined use of GIS, GPS, and a modelling language relies on the capacity to handle the huge amount of data related problem (Fabien et al., 2005).

Various forecasting methods including historical profile approaches, neutral networks, non-time series models, traffic assignment models are being developed by researchers of intelligent transportation system (ITS). One of the critical elements of intelligent transportation system (ITS) is forecasting the travel time.

Although network analysis in GIS has been largely limited to the simplest routing functions, the recent past has seen the development of object oriented data structures, the introduction of dynamic networks (Sutton and Wyman, 2000), the ability to generate multi-modal networks, and the use of simulation methods to generate solutions to network problems. Some network flow modeling functions have also been implemented, although there are substantial opportunities for additional theoretical advances and diversified application.

\subsection{Materials and Methods}

\subsection{Study area}

The study area is Minna, which is the capital of Niger State. It lies between Latitude $9^{\circ} 33^{\prime} \mathrm{N}$ and $9^{\circ}$ $40^{\prime} \mathrm{N}$ and Longitude $6^{\circ} 29^{\prime} \mathrm{E}$ and $6^{\circ} 35^{\prime} \mathrm{E}$. Minna lies on a valley bed (i.e. lowland) bordered to the east by Paida hill stretching eastwards toward Maitumbi and northwards to Maikunkele village. To the west and the southward is highland, with an area essentially savanna and quite conducive for farming. It has a distinct wet season as well as dry season.

\subsection{Data acquisition}

Data acquisition is the process of data gathering. This process involves the use of high resolution remote sensing images in analyzing, and mapping out the existing road network within the study area. The field survey aspects involved measuring of road parameters, traffic count; coordinates captured were also taken, with this computer assisted surveying method the quality and integrity as well as the completeness of the data are ensured. Verbal interview was adapted to capture relevant attribute data from commuters, and transporters and other well-placed citizens in areas of implementation. For the purpose of this study, a street guide map of Minna and High Resolution Satellite Imagery of Minna were used.

The positions in terms of spatial data $x$ and $y$ coordinates of the map were taken before on-screen scanning and digitization in order to provide spatial information about the project area. In this study, two types of data were captured.

In Geographic Information System (GIS), there is wide variety of data sources, though all fall into two categories of primary and secondary data. Data used in the Geographic Information system are primary in nature. Quick Bird image with $0.6 \mathrm{~m}$ resolution was acquired from GIS Vendor; traffic counts data were collected during the field survey.

Satellite image was acquired to aid in digitizing the road network of the study area. The QuickBird satellite is a high-resolution satellite operated by space imaging. This satellite image was used because of its high level of accuracy in mapping. Its capabilities include capturing a $3.2 \mathrm{~m}$ multispectral, near infrared (NIR)/0.82 panchromatic resolutions at nadir. It can yield relevant data for transportation study. 
It is essential to convert spatial and attribute data collection into a form which can be used for a geographic information system (GIS) where it is not in that format. Analogue maps, aerial photos and satellite imageries have to be converted into digital forms before they can be used; this can be achieved using GIS software and can be carried out in two ways - tablet and on-screen digitization. In this study ArcGIS 9.3 was used for digitizing, and analysis.

To ensure accuracy and certain level of precision, points that are identifiable on the QuickBird images acquired were selected for image geo-referencing. A minimum of four (4) ground control points were selected for the geo-referencing. The ground control point's readings were taken using hand held global positioning system (GPS) receiver (Garmin 12xs). These points were used to geo-reference the satellite image in readiness for digitization. The images were geo-referenced using Minna street guide map with its coordinates. The map was produced by the process popularly known as map-to-spatial data registration.

Tablet or manual digitizing was used for map encoding where it is important to reflect the topology of features since information about the direction of line feature can be included. The digitizing tablet senses $X$ and $Y$ position of the puck as the feature of the map placed on the digitizing tablet are traced and communicate these to digitizing software. Most digitizing software allows the "user" register the map on the digitizing tablet. This process establishes the relationship between the tablets coordinates system and the coordinate system of the paper map. The software compares the tablet coordinates and the map coordinates for a set of control points and then derives a best-fit translation function. This translation function is then applied to all the coordinates sent from the tablet to the software.

\subsection{Results and Discussion}

Road network map of the study area was produced using a high resolution satellite imagery of Minna. Analysis of Road Traffic Network of Kpakungu was developed showing the positioning of the major roads within and around the study area, to obtain road related attribute data and produce an alternative route in an event of traffic congestion. Geographical Information System adopted was very relevant in this analysis. The High Resolution Satellite Imagery of Minna used made it very easy to digitize the existing road network of Minna and was later used for proposing an alternative road. Road Network of Minna was digitized and labelled accordingly (Figure 1).

Field survey was carried out in the study area to collect related attribute information about traffic congestion in the area; traffic count was carried out at peak and off peak periods. Four major roads were focused on in the study, section "A" are vehicles coming to Kpakungu from various places like Bosso, Dutsen Kura, Maitumbi, Kateren Gwari, Fadikpe. Section "B" are vehicles coming to Kpakungu from Chanchaga, Tunga, Sauka-kahuta and Barikin-Sale and section "C" are vehicles going towards Bida Road. The traffic count was carried out at different periods. The first period was in the morning between $7 \mathrm{am}$ to $10 \mathrm{am}$ and the second period was between $4 \mathrm{pm}$ to $7 \mathrm{pm}$.

\subsection{Use of satellite imagery to map out congestion area in Kpakungu}

Analysis from the field survey and statistical analysis have shown the high number of motorcycles (Okada), taxis and private cars that ply the roads. This was complimented with GIS analysis to produce congestion area map of the study area. The satellite imagery of the study area (Kpakungu) is shown in Figure 2 and traffic congestion area map in Figure 3. 


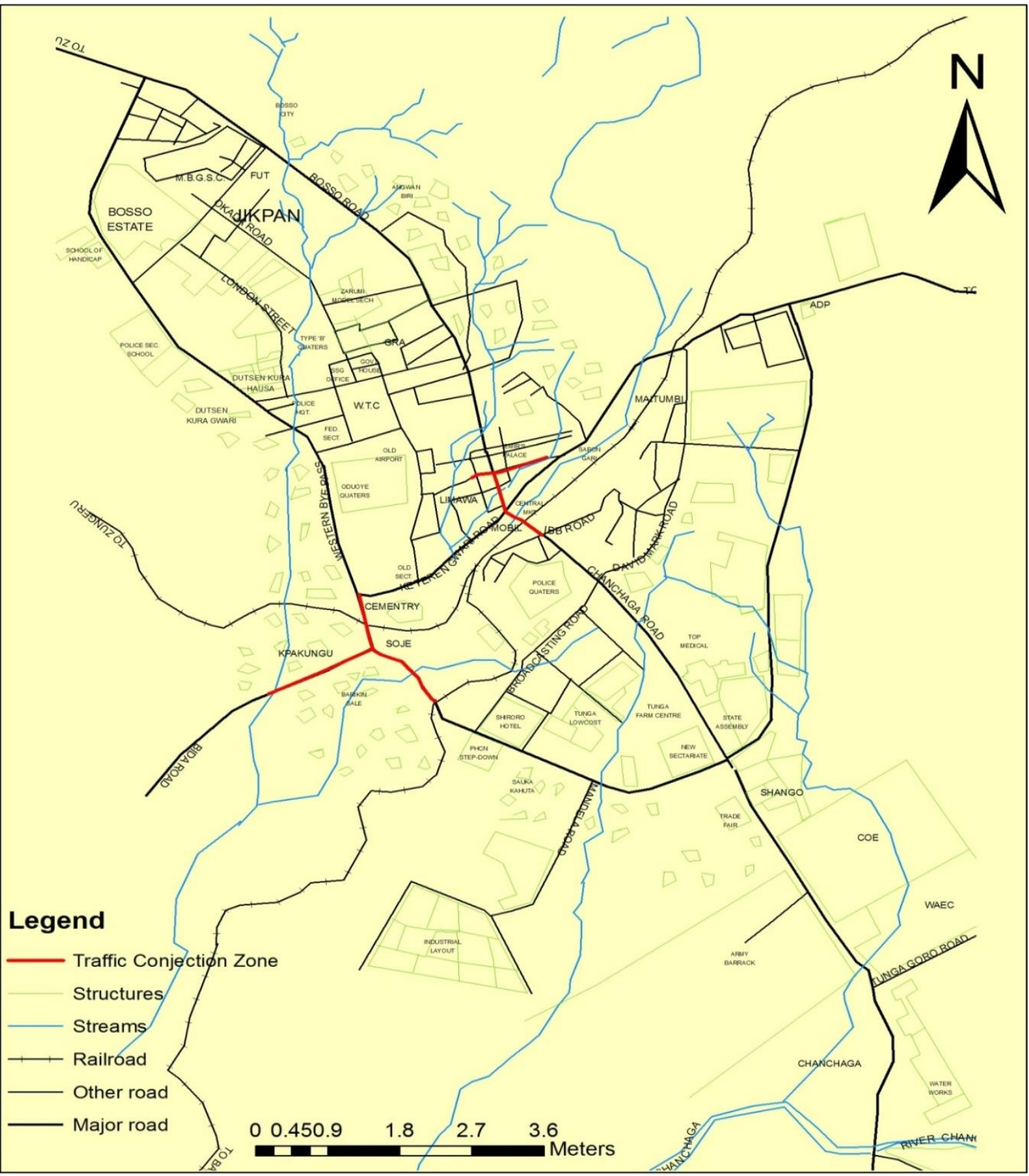

Figure 1: Digitized road network map of Minna 


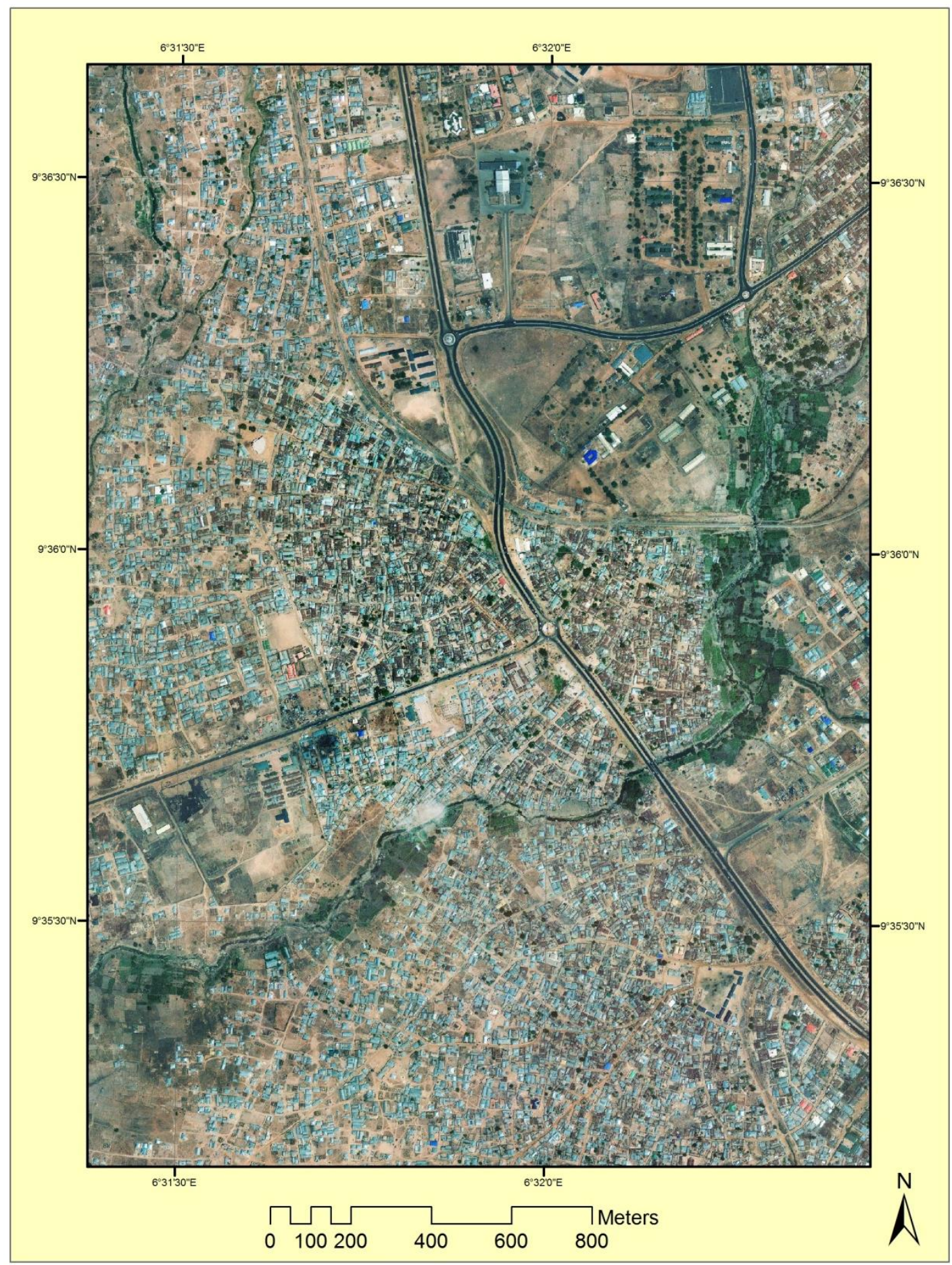

Figure 2: Satellite imagery of Kpakungu 


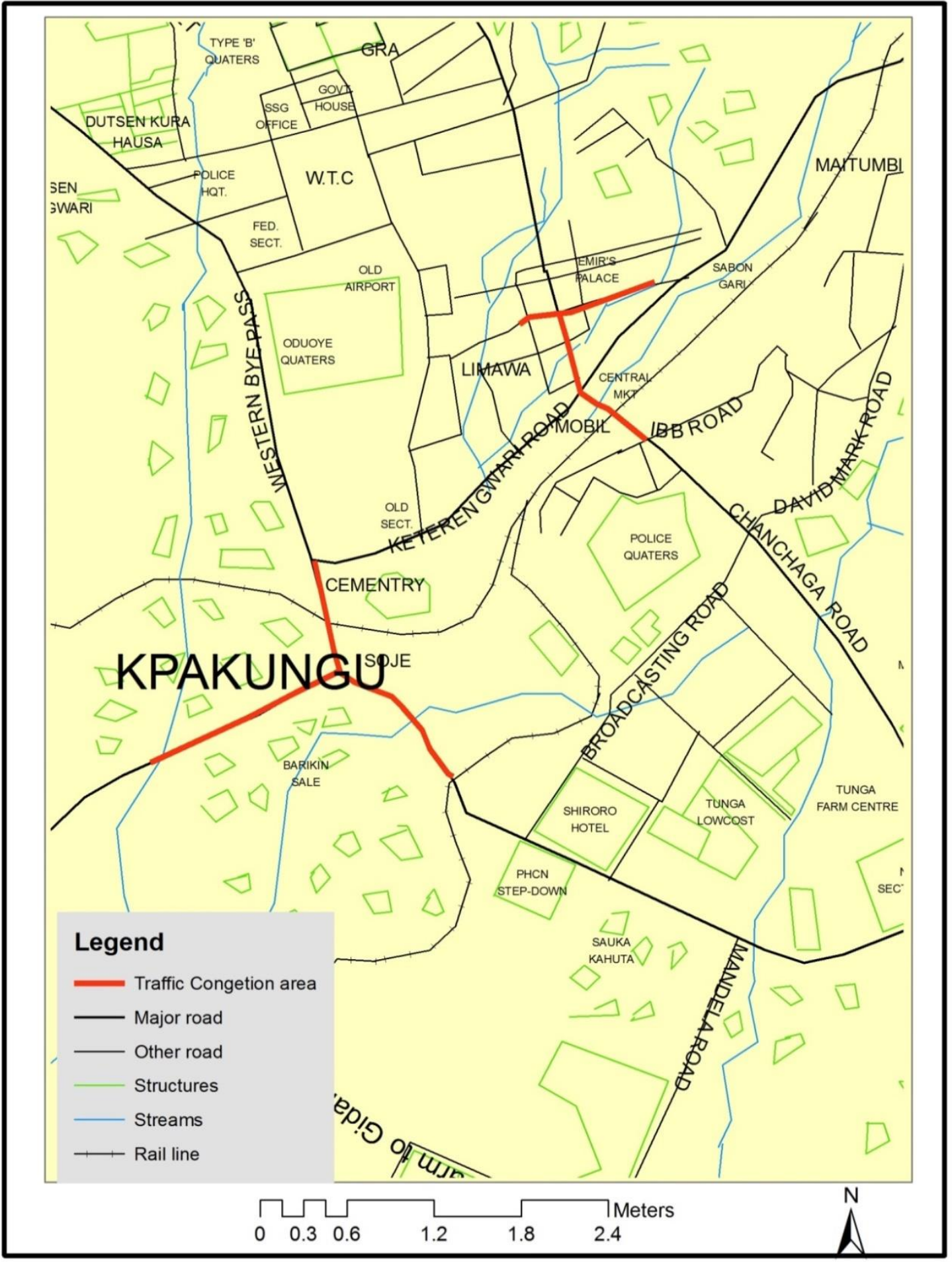

Figure 3: Traffic congestion map of Kpakungu

\subsection{Alternative route to take in order to bypass traffic congestion at Kpakungu (alternative routes)}

In proposing an alternative route to ply by different vehicles to reduce the pressure of traffic congestion in Kpakungu, field survey was carried out in selection and mapping of new roads in the area. GPS was used to track new route that can serve as an alternative route in order to reduce the pressure of traffic along Kpakungu road. The first alternative tracking was carried out from Aliyu Maiyaki Street opposite the Central Market to Gbeganu in order to reduce the traffic of vehicles coming from Bosso and Dutsen Kura going to Gidan Kwanu or Bida as well as NECO office (Table 1). The second was from Keteren Gwari Roundabout to reduce pressure of vehicles coming from 
Maitumbi and Minna Central going to Bida road (Table 2) and the third was from Industrial layout road (Talba Farm) to reduce traffic coming from Chanchaga going to Gidan Kwanu or Bida (Table 3). Alternative route was mapped out through the high resolution satellite map of the study area.

Table 1: GPS tracking coordinates of first alternative route (Aliyu Maiyaki Street to Gbeganu)

\begin{tabular}{|c|c|c|c|}
\hline $\mathrm{S} / \mathrm{N}$ & Latitude & & Longitude \\
\hline 1 & $09^{\circ} \quad 35$ & $37.2^{\prime \prime}$ & $006^{\circ} 31^{\prime} \quad 11.5^{\prime}$ \\
\hline 2 & $09^{\circ} 35^{\prime}$ & $47.7^{\prime \prime}$ & $006^{\circ} \quad 31^{\prime} 07.3^{\prime \prime}$ \\
\hline 3 & $09^{\circ} 36^{\prime}$ & 03.14" & $006^{\circ} 31^{\prime} \quad 06.3^{\prime \prime}$ \\
\hline 4 & $09^{\circ} 36^{\prime}$ & $03.7^{\prime \prime}$ & $006^{\circ} 31^{\prime} \quad 06.9^{\prime \prime}$ \\
\hline 5 & $09^{\circ} 36^{\prime}$ & $22.4^{\prime \prime}$ & $006^{\circ} 31^{\prime} \quad 06.3^{\prime \prime}$ \\
\hline 6 & $09^{\circ} 36^{\prime}$ & $22.0^{\prime \prime}$ & $006^{\circ} \quad 31^{\prime} \quad 07.5^{\prime}$ \\
\hline 7 & $09^{\circ} 36^{\prime}$ & $39.3^{\prime \prime}$ & $006^{\circ} 31^{\prime} \quad 05.1^{\prime \prime}$ \\
\hline 8 & $09^{\circ} 36^{\prime}$ & 41.3"' & $006^{\circ} 31^{\prime} \quad 05.5^{\prime \prime}$ \\
\hline 9 & $09^{\circ} 36^{\prime}$ & $44.6^{\prime \prime}$ & $006^{\circ} 31^{\prime} \quad 08.8^{\prime \prime}$ \\
\hline 10 & $09^{\circ} 37^{\prime}$ & $03.9^{\prime \prime}$ & $006^{\circ} 31^{\prime} \quad 12.1^{\prime \prime}$ \\
\hline 11 & $09^{\circ} 37^{\prime}$ & $06.2^{\prime \prime}$ & $006^{\circ} 31^{\prime} \quad 13.9^{\prime \prime}$ \\
\hline 12 & $09^{\circ} 37^{\prime}$ & $08.0^{\prime \prime}$ & $006^{\circ} 31^{\prime} \quad 14.6^{\prime \prime}$ \\
\hline 13 & $09^{\circ} 37^{\prime}$ & $09.1^{\prime \prime}$ & $006^{\circ} 31^{\prime} \quad 14.9^{\prime \prime}$ \\
\hline
\end{tabular}

Source: Field survey, 2016

Table 2: GPS tracking coordinates of second alternative route (Ketren Gwari roundabout to Nice Travel Bida Road)

\begin{tabular}{|c|c|c|}
\hline $\mathrm{S} / \mathrm{N}$ & Latitude & Longitude \\
\hline 1 & $09^{\circ} \quad 35^{\prime} \quad 47.6^{\prime \prime}$ & $006^{\circ} 31^{\prime} \quad 45.1^{\prime \prime}$ \\
\hline 2 & $09^{\circ} \quad 35^{\prime} \quad 53.0^{\prime \prime}$ & $006^{\circ} 31^{\prime} \quad 38.4^{\prime \prime}$ \\
\hline 3 & $09^{\circ} \quad 35^{\prime} \quad 59.7^{\prime \prime}$ & $006^{\circ} 31^{\prime} \quad 35.5^{\prime}$ \\
\hline 4 & $09^{\circ} \quad 36^{\prime} \quad 01.7^{\prime \prime}$ & $006^{\circ} 31^{\prime} \quad 34.3^{\prime \prime}$ \\
\hline 5 & $09^{\circ} \quad 36^{\prime} \quad 04.6^{\prime \prime}$ & $006^{\circ} 31^{\prime} \quad 33.7^{\prime \prime}$ \\
\hline 6 & $09^{\circ} 36^{\prime} \quad 05.5^{\prime \prime}$ & $006^{\circ} 31^{\prime} \quad 34.7^{\prime \prime}$ \\
\hline 7 & $09^{\circ} \quad 36^{\prime} \quad 10.2^{\prime \prime}$ & $006^{\circ} 31^{\prime} \quad 35.9^{\prime \prime}$ \\
\hline 8 & $09^{\circ} \quad 36^{\prime} \quad 06.7^{\prime \prime}$ & $006^{\circ} 31^{\prime} \quad 39.0$ '” \\
\hline 9 & $09^{\circ} \quad 36^{\prime} \quad 07.2^{\prime \prime}$ & $006^{\circ} 31^{\prime} \quad 43.9^{\prime \prime}$ \\
\hline 10 & $\begin{array}{lll}09^{\circ} & 36^{\prime} & 06.1^{\prime \prime}\end{array}$ & $006^{\circ} 31^{\prime} \quad 47.0^{\prime \prime}$ \\
\hline 11 & $09^{\circ} \quad 36^{\prime} \quad 06.1^{\prime \prime}$ & $006^{\circ} \quad 31^{\prime} \quad 48.0{ }^{\prime \prime}$ \\
\hline 12 & $09^{\circ} \quad 36^{\prime} \quad 05.4^{\prime \prime}$ & $006^{\circ} \quad 31^{\prime} \quad 50.9^{\prime \prime}$ \\
\hline 13 & $09^{\circ} \quad 36^{\prime} \quad 02.1^{\prime \prime}$ & $006^{\circ} \quad 31^{\prime} \quad 53.2^{\prime \prime}$ \\
\hline
\end{tabular}

Source: Field survey, 2016

Table 3: GPS tracking coordinates of third alternative route (Industrial layout road to Gidan Kwanu)

\begin{tabular}{|c|c|c|c|c|}
\hline $\mathrm{S} / \mathrm{N}$ & \multicolumn{2}{|l|}{ Latitude } & \multicolumn{2}{|c|}{ Longitude } \\
\hline 1 & $09^{\circ} 34^{\prime}$ & $15.0^{\prime \prime}$ & $006^{\circ} 33^{\prime}$ & 11.2" \\
\hline 2 & $09^{\circ} 34^{\prime}$ & $34.9^{\prime \prime}$ & $006^{\circ} 33^{\prime}$ & $03.7^{\prime \prime}$ \\
\hline 3 & $09^{\circ} 34^{\prime}$ & $23.9^{\prime \prime}$ & $006^{\circ} \quad 32$ & $56.5^{\prime \prime}$ \\
\hline 4 & $09^{\circ} 34^{\prime}$ & $02.0^{\prime \prime}$ & $006^{\circ} 32^{\prime}$ & 45.3'” \\
\hline 5 & $09^{\circ} \quad 33^{\prime}$ & $55.8^{\prime \prime}$ & $006^{\circ} \quad 32^{\prime}$ & $29.7^{\prime \prime}$ \\
\hline 6 & $09^{\circ} \quad 34^{\prime}$ & $14.2^{\prime \prime}$ & $006^{\circ} 32^{\prime}$ & $00.9^{\prime \prime}$ \\
\hline 7 & $09^{\circ} \quad 33^{\prime}$ & $59.4^{\prime \prime}$ & $006^{\circ} 31^{\prime}$ & $51.8^{\prime \prime}$ \\
\hline 8 & $09^{\circ} \quad 33^{\prime}$ & $54.7^{\prime \prime}$ & $006^{\circ} 31^{\prime}$ & $42.5^{\prime}$, \\
\hline 9 & $09^{\circ} \quad 33^{\prime}$ & $47.6^{\prime \prime}$ & $006^{\circ} 31^{\prime}$ & $32.7^{\prime \prime}$ \\
\hline 10 & $09^{\circ} \quad 33^{\prime}$ & $41.5^{\prime}$ & $006^{\circ} 31^{\prime}$ & $24.2^{\prime \prime}$ \\
\hline 11 & $09^{\circ} \quad 33^{\prime}$ & $24.8^{\prime \prime}$ & $006^{\circ} 31^{\prime}$ & $01.8^{\prime}$ \\
\hline 12 & $09^{\circ} \quad 33^{\prime}$ & $04.1 "$ & $006^{\circ} \quad 30^{\prime}$ & $34.4^{\prime \prime}$ \\
\hline 13 & $09^{\circ} \quad 32^{\prime}$ & $57.7^{\prime \prime}$ & $006^{\circ} 30^{\prime}$ & $31.3^{\prime \prime}$ \\
\hline
\end{tabular}

Source: Field survey, 2016 


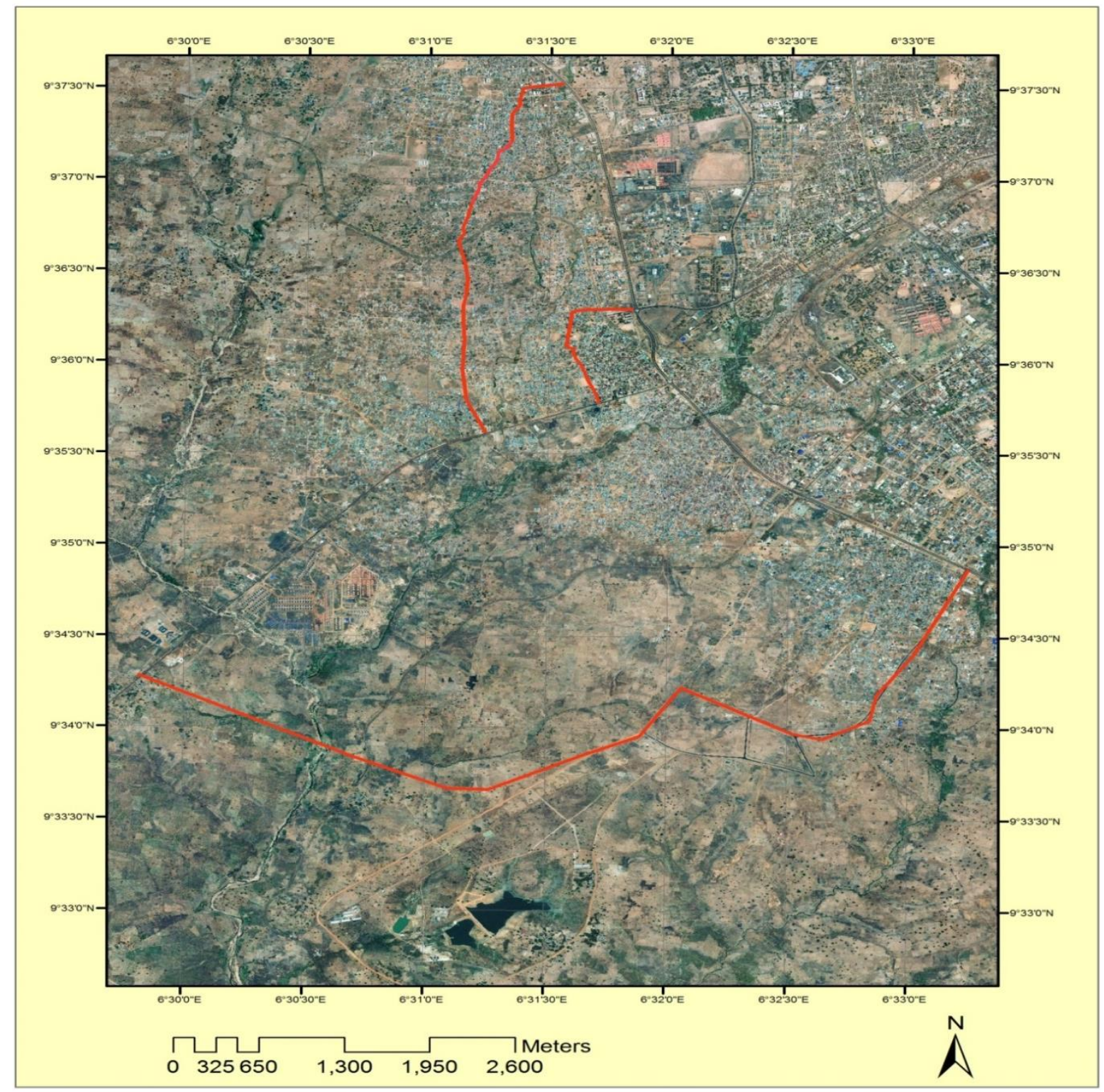

Figure 4: Satellite imagery showing the three proposed alternative routes 


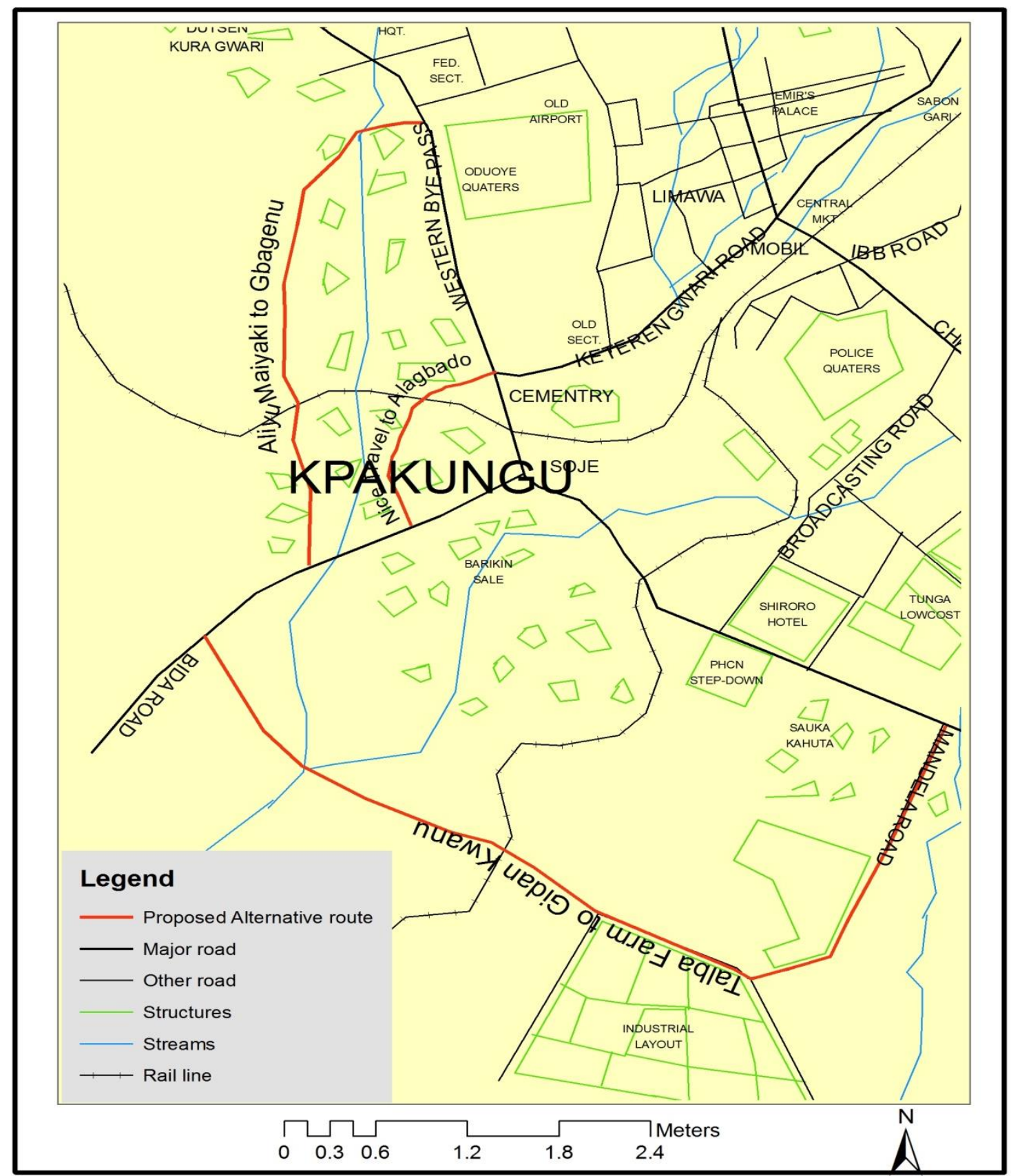

Figure 5: Digitized proposed alternative routes

It was also discovered that the causes of the traffic pressure in the study area was as a result of the relocation of FUT to its permanent site in Gidan Kwanu and the relocation of NECO Headquarter. Majority of the traffic pressure in the area are as a result of vehicles coming from Maikunkele, Bosso, Maitumbi, Minna central, Dutsen Kura, Chanchaga, Tunga, Sahuka-kahuta and Barikin-sale going to Bida, Gidan-Kwanu or NECO office.

\subsection{Conclusion}

Road traffic volumetric and spatial traffic distributions in Kpakungu have been studied to ascertain the road networking system of the area. GIS technique used was very useful to generate the road network of the study area. The importance of this research work is to map out the road network, identify congestion area and propose an alternative route to reduce congestion on the road. 
The analysis was interpreted to compute the volume of vehicles on the road network at the time of data acquisition and the possible ways to avoid overcrowding (traffic congestion) of cars in the area. Manual traffic count was carried out in Kpakungu for ground truthing and to make available firsthand information by creating geo-spatial attribute of traffic situation in Kpakungu.

It was also gathered that traffic congestion in the study area was as a result of the poor intercity road network, people going to Bida road like NECO Office, FUT Gidan Kwanu from Maikunkele, Bosso, Dutsen Kura, Minna central, Maitumbi, Chanchaga from any part of Minna must pass through the study area (Kpakungu Roundabout) which makes the place to be more congested. An alternative route need to be made available for people coming from Chanchaga to bypass the roundabout, as well as people coming from Bosso to have an alternative and people within Minna central area should also have an alternative in order to reduce the congestion on the road.

Based on the results of this study, the following recommendations are made:

i. The relevant authorities concerned with management of road and traffic control should be computerized to facilitate the use of geospatial data.

ii. The government should make the Bida road a dual carriage road by expanding the road.

iii. Geoinforrmatics techniques should be adopted in traffic control and planning.

iv. A map showing the available road network should be produced and updated to make research like this easier.

\section{References}

Ammar, A., Sitalakshmi, V., Jemal, A. and Mamoun, A. (2011). An Optimal Transportation Routing Approach using GIS-based Dynamic Traffic Flows. In: Proceedings $3^{\text {rd }}$ International Conference Information and Financial Engineering IPEDR, Singapore, 12, pp. 172-178.

Erkut, E., Fenske, R., Kabanuk, S., Gardiner, Q., Davis, J, (2001). Improving the emergency delivery in St. Albert. INFOR 2001, 30, pp. 416-433.

Fabien, M., Martin, T. and Andre, L. (2005). Road network monitoring: Algorithms and a case study. Computer Science and Operations Research. In-press corrected proof Available online 23, May, 2005.

Garba, Z. W. (2002). Soil erosion. A major cause of land degradation in Minna and environs. Causes effects and solution. Unpublished M.Tech. Thesis, Department of Geography, Federal University of Technology, Minna.

Golderg, D. (2011). Advances in Geocoding Research and Practice. Transactions in GIS, 15(6), pp. $727-733$.

Harrington, A. and Cahill, A. (2004). Route profiling Putting Context to Work, Department systems Group, Department of computer science, Trinity College Dublin.

Leke, O. (2007). Effects of Institutional Land Uses on Road Traffic in Metropolitan. The Social Science, 2(3), pp. 255-263.

Longley, P., Goodchild, M. D. and Rhind, D. (2001). Geographic Information Systems and Science. Wiley, New Jersey, U.S.A.

Mukti, A., Srirama, B. and Pathan, S. K. (2005). Improvement in Transit Service using GIS - Case study of Bhavnagar State Transport Depot. In: Proceedings ESRI National Conference 2005 held at NOIDA, India, pp. 1-7.

Ogunbodede, E. F. (2011). Assessment of Traffic Congestions in Akure (Nigeria) using GIS approach: Lessons and Challenges for urban sustenance. Department of Geography \& Planning

Sciences, pp. 1-25. 
Rodrigue, J., Comtois,C. and Slack, B. (2006). The Geography of Transport Systems. London, U.K. Routledge.

Sutton, J. C. and Wyman, M. M. (2000). Dynamic location: An iconic model to synchronize temporal and spatial transportation data. Transportation Research Part C-Emerging Technologies 8(1-6), pp. $37-52$.

Thill, J. C. (2000). Geographic information systems for transportation in perspective. Transportation Research Part C: Emerging Technologies, 8(1-6), pp. 3-12. 